\title{
European Pension Privatisation: Taking Account of Gender
}

\author{
Jay Ginn \\ Centre for Research on Ageing and Gender, Department of Sociology, University of Surrey \\ E-mail: j.ginn@surrey.ac.uk
}

Debate on pension privatisation in Europe has provided useful insights into the diversity of European pension systems in terms of ideological orientation, design features and reform paths followed. However, the gender dimension has often been neglected. Thus a recent analysis states that, depending on predominant social values, pension privatisation may be 'consistent with the notion of collective responsibility for needs-satisfaction' (Hyde et al., 2003: 189). Yet the unequal effects of privatisation on men and women are ignored. This article argues that, despite considerable variation among countries in the nature of their private pension schemes, the latter share a failure to incorporate allowances for periods of unpaid caring work over the lifecourse. Comparison of the needs-satisfying capacity of private and public pensions must take account of the situation of those who raise the next generation of producers and taxpayers.

\section{Introduction}

Pension privatisation - shifting the balance of pension provision away from public provision and towards the private sector - has taken a variety of forms across Europe, depending on dominant societal values and on political feasibility. A recent article in this journal (Hyde et al., 2003) has highlighted this diversity and the importance of ideological orientation in shaping pension reforms. In particular, these authors point out that the neoliberal (or Regulated Market) model of privatisation, exemplified by Britain, has attracted criticism and concern about intensification of poverty among older people, yet is only one of several alternative models of pension privatisation. Other models include the Social Partners model, expressing a social reformist ideology and the Social Market model, expressing reluctant individualism. These alternative models and orientations towards pension reform are exemplified by France and Finland respectively.

Hyde et al. (2003) challenge two assumptions they claim underlie the concerns of critics: first, that pension privatisation is necessarily informed by neo-liberal, anticollectivist values, and, second, that an aim of pension privatisation is to reduce the welfare role of the state, to the detriment of the satisfaction of needs. Their analysis is a useful corrective to a narrowly Anglocentric focus and a plausible case is made that pension privatisation reforms may be driven by other reasons than anti-collectivism. For example, they suggest that if popular control of welfare through labour or community organisations is to be enhanced, this requires some form of privatisation. Although that claim is debatable, it is not the focus of this article. It is the second belief challenged by Hyde et al. (2003) - that pension privatisation is driven by the aim of welfare retrenchment and that this could erode collective responsibility for the welfare of the vulnerable - that I wish to defend here. 
This article examines how the mix of private and state pensions perform for one vulnerable group, women whose family caring commitments result in fragmented employment patterns and earnings. A framework for evaluating pension schemes in terms of their women-friendliness is outlined and European state and private pension systems compared. The remainder of the article considers whether a benign form of pension privatisation, in which women and other low paid groups are not disadvantaged, is possible.

\section{Gender, caring and pensions}

The caring commitments entailed in motherhood (or in having frail parents) constrain women's employment, earnings and ability to contribute to pension schemes in most countries (Ginn et al., 2001; Ginn, 2003) although the impact of caring is greater in some countries than others. Harkness and Waldfogel (1999) show that among women aged 25-44, mothers' employment participation was substantially less than that of childless women or of men in five European countries studied - Germany, France, Sweden, Finland and the UK - but the effect of children was greatest in the UK and negligible in Sweden. This 'family gap' was even more striking for full-time employment. For example, 76 per cent of British women without children were employed full time compared with only 26 per cent of women who had children, while the equivalent rates were 72 and 40 per cent in Germany, 75 and 61 in Sweden and 79 and 66 per cent in Finland (Harkness and Waldfogel, 1999). For lone mothers (divorced, never married or widows) the problem of obtaining affordable childcare is more acute than for married mothers, magnifying the effect of motherhood on their employment.

Where childcare requirements continue to restrict mothers' participation in paid work, women's full-time employment rate cannot be expected to rise substantially. Moreover, despite equalities legislation, gender differences in hourly pay, occupational status and career trajectories persist in the EU. These continuing inequalities limit the prospects of gender convergence in the capacity to build independent contributory pension entitlements.

Welfare states both construct and reward particular uses of time through the rules of public pension schemes (Schiewe, 1994) and this is also the case for private pensions. Pension entitlements are maximised by continuous full-time employment throughout the years from 20 to 65 and may also depend on the individual's earnings trajectory over the working life. The extent of women's disadvantage in acquiring pensions varies considerably among European pension systems, as discussed in the next section.

\section{A gender-sensitive approach to pension systems}

Analysis and debate about pension systems has predominantly focused on state/market relations, while gender and family roles have been relatively neglected (Orloff, 1993). Thus Hyde et al. (2003) argue that the neo-liberal model of private pensions is only one model and that others exemplified in Europe are less market oriented and hence allow more scope for expressing the values of social cohesion, integration and inclusion. Yet these authors' otherwise useful analysis does not consider whether pension privatisation will exacerbate women's pension disadvantage irrespective of societal values and the particular reform model adopted. 
Table 1 Key components of pension systems from a gender perspective

(a) State pensions (individual entitlement)

Access

Earnings or hours thresholds for contributions

Years threshold for residence-based pension

The treatment of years of caring

Age for pension qualification

Amount

Whether and how pensions are linked to earnings

The existence of minimum floors and/or ceilings

Maximum amount as \% of average earnings

Duration of contribution/residence period for full pension

(b) State pensions (entitlements as dependant)

Access

Amount

\section{(c) Private pensions}

Access

Amount
Married or widowed status required for eligibility

Provision for pension splitting on divorce

Whether dependant's entitlement equals that of contributing spouse

$\%$ allocated to wife, if unequal entitlement

$\%$ 'inherited' by widow

Arrangements for divorcees

Private pension provision mandatory or not

Earnings or duration of service threshold for eligibility

Ease of transfer or preservation for early leavers

Defined contribution or defined benefit

Level of employer's mandatory contribution, if any

Whether entitlement is inflation-proofed during preservation

Whether pension in payment is inflation-proofed

Level of tax relief on contributions, if any

Widow's pension as \% of deceased member's pension

Source: Ginn et al., 2001, chapter 1.

A gender-sensitive analysis of pension systems examines how the rules privilege particular forms of time use. The tighter the link between pension entitlements and employment career the stronger will be the gender differences in pension entitlements. Redistributive mechanisms that loosen the link between past earnings and pension entitlements tend to benefit women, especially those whose caring commitments have reduced their contribution record (Rake, 1999). In the pension system as a whole, the relative shares of state and private pensions are also important.

Table 1 sets out the key features of a pension system in terms of pension quality for women, distinguishing four sources of income in later life (Ginn et al., 2001). Genderrelevant aspects of state and private pensions for the individual and of derived pensions are next examined. Public and private pensions are then considered in terms of how well they meet the needs of those who have taken on caring commitments.

\section{State pensions (individual entitlement)}

In state pension provision, minimum or flat-rate pensions and those based on best earning years all help women to obtain an independent pension, as does recognition of care work 
Table 2 Allowances for childcare or eldercare in state pension schemes

\section{(a) Flat rate schemes}

Britain

Ireland

Denmark

Netherlands

\section{(b) Earnings related schemes}

Finland

Sweden

Austria

Germany

France

Belgium

Portugal

Luxembourg

Spain

Italy

Greece

Denmark (ATP)

Britain (SERPS/State Second Pension)
Home Responsibilities Protection for those with children up to 16 (or 18 in full-time education) and for those providing substantial care for adults

Homemakers Scheme as above

Universal tax-funded Social Pension (residence-based)

Universal pension (residence-based)

Coverage for recipients of home care allowance

4 years coverage for each child

4 years coverage for each child

3 years coverage for each child, based on national average earnings; informal carers covered, benefit depending on hours of care provided

2 years coverage for each child; bonus for mothers of 3 children

2 years coverage for each child, based on individual's last wage

2 years coverage for each child

2 years coverage for each child

1 year coverage for each child

6 months coverage for each child;

$1 \mathrm{month} /$ year coverage for informal carers

3-6 months coverage for each child

None, but pension related to hours not earnings

None in SERPS but its replacement from 2002, the State Second Pension, includes coverage until the youngest child is aged 6

Source: Adapted from Leitner, 2001, Tables 4 and 5.

for entitlement purposes. Most EU state pension schemes make some form of allowance for years of caring for children - and some also allow for informal care of frail adults as shown by Leitner (2001) (see Table 2). Two of the flat rate schemes (Britain and Ireland) have since the 1970s provided for those with caring responsibilities by reducing the number of qualifying years required for a full basic pension. In Denmark and the Netherlands, a tax-funded 'citizen's pension' is payable to all those fulfilling residence requirements, at age 67 in Denmark and 65 in the Netherlands. Thus those who have spent years providing care receive the same basic pension as those who have been continuously employed. In 2002 the Dutch universal flat rate pensions provided $€ 203$ (about $£ 140$ ) per week to each lone pensioner plus a holiday allowance, and the pension is indexed to the minimum wage. In stark contrast, the full British basic pension in 2002 was only $£ 77$ per week (about 15 per cent of average earnings) undermining its effectiveness 
as an instrument to redistribute towards carers. This large difference in the generosity and comprehensiveness of the Dutch and British basic pensions, where both countries have a large private pensions sector, is likely to reflect their different orientations to welfare.

In earnings related pension schemes, the value of a carer's credit depends on the notional contribution rate applied for the period covered, which may be a fraction of national average earnings or of the individual's recent earnings. Another gender-relevant factor in earnings related schemes is the number of years used in calculating the average earnings on which the pension entitlement is based (Leitner, 2001). Half of the EU countries with an earnings related scheme use lifetime earnings (Belgium, Germany, Italy, Luxembourg, Sweden, Britain); in these countries periods of no/low pay will tend to reduce the average on which the pension is based, unless those periods are entirely covered by pension credits. The remainder use average earnings during last or later years (Finland, Greece, Spain) or the average in the best years (Austria, France, Portugal). Since women's earnings are not necessarily highest towards the end of the working life (as is often the case for men, especially in non-manual occupations) use of best years is more helpful to women than use of last years.

In sum, most state pension schemes in the EU include some provision to compensate for women's disadvantages arising from their interrupted and part-time participation in the labour market, although the redistribution in favour of carers varies widely across the EU. Despite a relatively generous system of crediting carers into state pensions, Britain stands out as having particularly low levels of state pensions. This reflects an increasingly strong neo-liberal welfare orientation since the 1970s that has also expanded reliance on private pension provision.

\section{Private pensions (occupational and individual)}

Membership of defined benefit occupational pensions is often unequally available to employees. Women's lower coverage relative to men reflects this, as well as their lower employment rate. In Britain, women have had less access to such schemes due to shorter hours of work, lower occupational status, shorter length of service and type of employer; part-timers often work for small private sector employers who do not operate an occupational pension scheme (Ginn and Arber, 1993). Moreover, part-timers and others on low wages (mainly women) often cannot afford the higher contributions required in an employer's pension scheme (Fawcett/Age Concern, 2003). For all these reasons, the benefit of the employer's contribution, which has generally ensured a better pension than that offered by individually arranged pension plans, is less available to women than men. Among employees who join a defined benefit occupational pension scheme, women are more likely than men to leave early due to caring commitments, losing the benefit of later wage growth. Even where women and men employees have similar coverage by such pension schemes (as in British public sector organisations) their lower earnings, shorter hours of work and gaps in employment all result in lower pension entitlements relative to men, mediated by class and ethnicity (Ginn, 2003).

Individual (or personal) pensions may be more widely accessible to workers, yet provide poor value for most women and for the low paid generally (Davies and Ward, 1992; Waine, 1995). As in any defined contribution scheme, contributions made early in the working life have a disproportionate effect on the fund at retirement but women's 
ability to contribute is often very limited until their children have become independent. Charges for administration, investment management and annuitization may reduce the value of contributions by 45 per cent (Murthi et al., 2001). It is estimated that 30-40 per cent of personal pension account holders in Britain found that charges actually exceeded the amount they had contributed (Disney and Johnson, 1997). British stakeholder pensions have charges capped at 1 per cent of the fund annually. Yet by retirement such charges may have reduced the fund by 25 per cent, while hidden charges (such as dealing costs) can absorb as much again. For the low or moderately paid, the loss due to charges combined with low annuity rates and the risk of poor investment performance, make personal pensions an expensive gamble. Women not only retire with a smaller accumulated fund than men but due to longer average life expectancy their annuity will be about 10 per cent lower than for men with the same fund - a double disadvantage.

Women not only have less financial resources to gamble with than men but are also more likely to feel uninformed about pensions (Hawkes and Garman, 1995). Across a range of OECD countries, women receive much less income from private pensions than men do, as shown later in this article.

\section{Derived pensions (state and private)}

Women's retirement income is influenced by their marital status, since pension schemes have traditionally provided spousal and survivors' pensions. But these fractional pensions based on a husband's contribution record are often inadequate, especially where the husband's own pension is small. In the twenty-first century, changing expectations concerning women's financial independence make derived pensions an unsatisfactory remedy for women's poorer independent pension entitlements. Moreover, derived pensions are becoming increasingly ineffective and ill-targeted, due to erosion of the link between marriage and motherhood.

Throughout developed societies, fertility is falling, as the expectation that women will bear and raise children as a matter of course has weakened. In Britain, a quarter of women born in 1972 are predicted to be still childless by age 45, compared with only 11 per cent of women born in 1943 (FPSC, 2000). Equally, the expectation that men and women will marry has declined. Thus the proportion of British women aged 18-49 who were married fell from three quarters in 1979 to only half in 2001, while those who were single (never married) doubled from 18 per cent to over a third and those who were divorced/separated nearly doubled from 7 to 13 per cent (ONS, 2002). The proportion of mothers who are married has also fallen. In 2001, only two thirds of women aged 16-59 with dependent children were married (ONS, 2002). Births outside marriage rose from 7 per cent in the early 1970s to 38 per cent in 1998 (ONS, 1999). Lone parent families (90 per cent headed by women) represent a quarter of all families (ONS, 2000a). The decline of marriage as a lifelong contract makes reliance on a husband for income in later life an increasingly risky strategy for women.

These social changes surrounding marriage and motherhood raise questions for EU policymakers about the wisdom of relying on marriage and derived pensions (public or private) to support older women. Spouse and survivor state pensions provide no help to those who have raised children outside marriage so that such women fall through the net. Derived pensions involve substantial cross-subsidies from other contributors to those who marry, but apply irrespective of caring commitments (Cuvillier, 1979; Jepsen and 
Table 3 Women's pension income relative to men's, in six OECD countries: non-married women and men aged over 70 , mid-1990s

\begin{tabular}{lccc}
\hline \hline & \multicolumn{3}{l}{ Women's mean amount as \% of men's } \\
\cline { 2 - 4 } & Public & Private & Total \\
\hline Britain & 92 & 40 & 69 \\
US & 90 & 54 & 78 \\
Germany & 77 & 74 & 77 \\
France & $\sim$ & $\sim$ & 74 \\
Finland & $\sim$ & $\sim$ & 75 \\
Sweden & 75 & 62 & 73 \\
Denmark & 100 & 91 & 99 \\
\hline \hline
\end{tabular}

Notes:

Britain: State Earnings Related Pension Scheme (SERPS) included with 'private'.

US: Supplemental Security Income (SSI) included with 'public'.

Germany: Public officials' pensions included as 'public'.

Denmark: Public officials' pensions included as 'public', also meanstested supplement.

$\sim$ The major pension schemes were not separated into public and private.

Source: Calculated from Makinen (2002), Figure 4.2.

Meulders, 2002). Thus non-married mothers, a group suffering multiple disadvantages, subsidise the derived pensions of childless married women. Similarly in defined benefit occupational pension schemes there are cross-subsidies from members who are not married - including lone parents - to members who are married since the latter pay no additional contribution into the scheme in respect of survivor benefits.

It is questionable whether this subsidy to marriage in state pensions and final salary occupational pension schemes is justifiable. But derived pensions cannot be phased out until there is improved pension protection for those with caring commitments. That implies improving state pensions, as shown in the next section.

\section{Public-private pensions mix: effects on gender inequality and poverty}

Personal income of married individuals is rarely analysed, due to the assumption of equal sharing within couples, although research has shown that gender inequality of later life income is greatest among those who are married (Ginn and Arber, 1991, 1999). Among non-married older people, such information on gender differences in income is more readily available. Makinen (2002) used Luxembourg Income Study data for the mid 1990s to compare non-married individuals' pension income in ten countries. Among those aged over 70, women's average pension income as a proportion of men's was lowest 69 per cent - in Britain, between 73 and 78 per cent in the US, Germany, France, Finland and Sweden, but nearly 100 per cent in Denmark (Table 3, column 3). In Britain and the US, where private pensions are relatively important, women's state pension income 
was over 90 per cent of men's but the gender gap was much wider in private pension income. Thus British non-married women aged over 70 received only 40 per cent of the private pension income of their male counterparts. In Germany and Sweden, the gender gap in state pension income was quite large, reflecting the earnings related structure of the social insurance scheme. In France and Finland, information distinguishing private and state pension income was not available. A high degree of gender equality of later life income is seen in Denmark, due mainly to the redistributive effect of the citizen's pension.

Gender inequality in private pension income varied across countries, being greatest in Britain and least in Denmark. While this appears to support Hyde et al.'s (2003) contention that the model of privatisation matters, differences in women's full-time employment rates and in the gender earnings gap contributed to these outcomes. Moreover, where a relatively small proportion of retired men and women have private pension income, these represent an occupational elite, in which women have predominantly pursued a career at the expense of raising a family. Among non-married women aged over 70, private pensions comprised on average under 2 per cent of their total income in Germany and 9 per cent in Denmark. In contrast, the equivalent figures for Sweden, Britain and the US were 15, 26 and 23 per cent respectively (Makinen, 2002: Figure 4.2). Table 3 demonstrates the potential for state pensions to equalize incomes between women and men, indicating that a shift towards the private sector can be expected to reinforce gender inequality.

The public-private mix in pension provisions has implications for pensioner poverty. The poverty rate for individuals aged over 65 in 1998, using the EU definition of income below 60 per cent of national median equivalized income, was 21 per cent in Britain (25 per cent for women, 17 per cent for men), compared with 11 per cent in Germany, 8 per cent in Sweden and 7 per cent in the Netherlands (CEC, 2003). Relative to the income of the average production worker, state pensions of non-married women aged over 65 were only 20 per cent in Britain, 25 per cent in the US, around 30 per cent in Canada, Italy and the Netherlands and over 40 per cent in Germany and Finland (Yamada and Casey, 2002: Table 5.5). The high poverty rates and low relative incomes of older women in the highly privatised systems of Britain and the US suggest a relationship with pension privatisation. But can we conclude that privatisation per se causes these adverse distributional outcomes?

\section{Benign pension privatisation - an unlikely scenario}

Since a neo-liberal ideological orientation to welfare leads to both low state provision and a well-developed private sector, it is difficult to disentangle causal relationships. The question raised by Hyde et al.'s (2003) article is: Can pension privatisation in the context of a relatively collectivist ideological climate avoid the intensification of pensioner poverty, especially among women? There are reasons to believe it cannot.

First, private pensions have public costs. For example, public spending on private pensions, mainly tax relief, grew dramatically under the Thatcher administration, reaching $£ 8.2 \mathrm{bn}$ in 1991 and $£ 13.7 \mathrm{bn}$ in 2000 . This was equivalent to over 40 per cent of state spending on the basic National Insurance pension (Sinfield, 2000) and amounted to 2.8 per cent of GDP (Adema, 2000). Moreover, the private pensions industry absorbs a substantial proportion of the public subsidy in management charges, especially in 
individually arranged pensions, as noted above. The public resources available to pay state pensions, on which women and the low paid depend heavily, are thus reduced. Subsidies to private pensions are highly regressive, with half the benefit received by the top 10 per cent of taxpayers and a quarter by the top 2.5 per cent (Agulnik and Le Grand, 1998).

Second, as private pensions spread first among the most secure and well-organised employees, a powerful constituency is established which will defend tax reliefs and other subsidies to private pensions but which is less motivated to defend declining state pensions. This process can be traced in Britain, where occupational pensions initially negotiated by organised workers as a fringe benefit developed into a lucrative industry that limited the scope for a state second tier pension (Shragge, 1984). Despite the belated introduction of the women-friendly State Earnings Related Pension Scheme (SERPS) by a Labour government in the 1970s, along with enhanced indexing and carer allowances in the basic pension, these improvements to state pensions were short-lived. Resistance by organised workers was insufficient to prevent the cuts imposed by the Conservative governments in the 1980s, at a time when the new personal pensions were being promoted with attractive financial incentives. From the point of view of the individual employee expecting a substantial private pension, state pensions may seem increasingly irrelevant, reducing willingness to pay contributions or join others in defending state pensions. This British scenario contrasts with the massive and effective resistance to government attempts to cut state pensions organised over this period by trade unions in Italy, Germany and France, where the majority of employees rely on state (or quasi-state) pensions. Privatising pensions may itself alter the ideological and political context, eroding social solidarity even where this is not an intended consequence.

Third, the transition costs of privatising pensions fall on the generation that is working at the time. Paying for both the existing state pension liabilities and their own funded private pensions, they bear an unfair share of the transition cost. A corollary is that pressure builds to reduce state pension contributions and hence the level of state pensions. The issue of what pension structure can best achieve intergenerational equity in an ageing population has been thoroughly explored by Schokkaert and van Parijs (2003). Applying the ethical principle that the ratio of pensioner incomes to those of workers should remain constant across generations - the Musgrave (1986) rule - these authors conclude that fair sharing of the cost of population ageing and risk of economic shocks among generations cannot be achieved by private funded pensions. Defined contribution pensions 'are intrinsically unable to achieve intergenerational risk sharing' (Schokkaert and van Parijs, 2003: 254) while occupational defined benefit schemes allow greater sharing of market risks but cannot maintain intergenerational equity if they have an ageing membership. These authors add that some pre-funding of Bismarckian state pensions may be required and they recommend a basic non-means tested universal minimum pension to ensure intra-generational redistribution and to reduce gender inequality in pension income.

Fourth, as shown by Toporowski (2000) large pension funds have large economic effects, fuelling stock market inflation, share price 'bubbles' and a crisis in private pension funding. Company pension schemes in Britain are increasingly closing to new members and offering defined contribution schemes instead, reducing the employer contribution at the same time so that projected pensions are often 30 per cent lower than in the original scheme. Some employers have wound up their scheme, with serious losses for workers whose expected pension has shrunk to a tiny fraction of its previous level. The British 
Association of Consulting Actuaries estimated that only two fifths of British occupational final salary pension schemes remain open to new members, with half of these considering closure (ACA, 2002). Private pensions are as much affected by increasing longevity as are state Pay-As-You-Go pensions, but have the additional risk of poor investment performance. The collapse of Equitable Life's pension guarantees after 1999 and the implosion of Enron in the US in 2002 demonstrated the limits of state regulation of private pensions, even after repeated scandals, investigations and attempts to tighten controls. Moreover, a pensions industry that initially cooperates with social partners may grow later into a powerful political actor in defence of its own interests. In Britain, a spate of government consultations has revealed the effectiveness of the private pensions industry in influencing pensions policy and resisting state regulation. The risks of market failure, incompetence and fraud in private pensions are not confined to neo-liberal welfare states but have wider relevance.

Fifth, the explicit aim of most OECD governments is to contain state pension spending, irrespective of differences in their traditional ideological orientations. The promotion of private pensions must be seen as part of this objective, a means of allowing (some) individuals to compensate for diminishing state pensions. Those who cannot do so, mainly women, manual workers and ethnic minorities, will face the indignities of means testing or the uncertainties of relying on family members for financial support. Benign pension privatisation, without intensification of poverty among the vulnerable, seems unlikely to occur.

\section{Conclusions}

This article has taken issue with the view that pension privatisation need not be to the detriment of social cohesiveness and the needs of the vulnerable, showing how women, in particular, are disadvantaged in private pensions. Comparing state and private pensions from a gender perspective showed that the former are better able to reduce the adverse effects of caring on women's pension income.

Although countries beginning to introduce private pensions appear to avoid the worst consequences of privatisation evident in countries with a neo-liberal orientation to welfare, it is suggested that if the share of private pensions grows, new political alliances could form based on a more individualistic ethos. In such a climate, defence of state pensions could weaken, leading to an increase in pensioner poverty and inequality.

\section{Acknowledgments}

I am grateful to the Sociology Department of Surrey University for financial support enabling me to write this paper.

\section{References}

ACA (2002), ACA Survey of Final Salary Schemes, www.aca.org.uk/public_content/June_2002_ACA_ SURVEY_OF_FINAL_SALARY_SCHEMES.doc.

Adema, W. (2000), 'Revisiting real social spending across countries: a brief note', OECD Economic Studies, 30, 191-197. 
Age Concern/Fawcett Society (2003), Simplicity, Security and Choice: A Joint Response on Women and Pensions, London: Age Concern/Fawcett Society.

Agulnik, P. and Le Grand, J. (1998), 'Tax relief and partnership pensions', Fiscal Studies, 19, 4, 403428.

CEC (Commission of the European Communities) (2003), Joint Report by the Commission and the Council on Adequate and Sustainable Pensions, Brussels: CEC.

Cuvillier, R. (1979), 'The housewife: an unjustifiable burden on the community', Journal of Social Policy, $8,1,1-26$.

Davies, B. and Ward, S. (1992), Women and Personal Pensions, London: EOC.

Disney, R. and Johnson, P. (1997), 'The UK: a working system of minimum pensions?', Paper presented to conference on Redesigning Social Security, Kiel Institute of World Economics, Kiel, 26-27 June.

EPC (Economic Policy Committee) (2001), Budgetary Challenges Posed by an Ageing Population, Brussels: EPC of the EC, and at http://europa.eu.int/comm/economy_finance/epc.en.htm

Family Policy Studies Centre (2000), 'New options and new ways of living', Families Today Factsheet, 1, 3-4.

Fawcett/Age Concern (2003), 'Pensions not a priority for women, says new research', press release 13 August, London: Fawcett Society/Age Concern England.

Ginn, J. (2003), Gender, Pensions and the Lifecourse: How Pensions Need to Adapt to Changing Family Forms, Bristol: Policy Press.

Ginn, J. and Arber, S. (1991), 'Gender, class and income inequalities in later life', British Journal of Sociology, 42, 3, 369-396.

Ginn, J. and Arber, S. (1993), 'Pension Penalties: The Gendered Division of Occupational Welfare', Work, Employment and Society, 7, 1, 47-70.

Ginn, J., Daly, M., and Street, D. (2001), 'Engendering pensions: a comparative framework', chapter 1 in J. Ginn, D. Street, and S. Arber (eds), Women, Work and Pensions: International Issues and Prospects, Buckingham: Open University Press.

Harkness, S. and J. Waldfogel (1999), 'The family gap in pay: evidence from seven industrialised countries', CASE paper 29. London: Centre for Analysis of Social Exclusion.

Hawkes, C. and Garman, A. (1995), 'Perceptions of non-state pensions', In-house Report 8, Department of Social Security, London.

Hyde, M., Dixon, J., and Drover, G. (2003), 'Welfare retrenchment or collective responsibility? The privatisation of public pensions in Western Europe', Social Policy and Society, 2, 3, 189-198.

Jepsen, M. and Meulders, D. (2002), 'The individualisation of rights in social protection systems', chapter 3 in H. Sarfati and G. Bonoli (eds), Labour Markets and Social Protection Reforms in International Perspective, Aldershot: Ashgate.

Leitner, S. (2001), 'Sex and gender discrimination within EU pension systems', Journal of European Social Policy, 11, 2, 99-115.

Makinen, T. (2002), 'Public or private? International comparison of the structure and level of pension income', paper presented to the ISA XV World Congress of Sociology, Brisbane 7-13 July.

Murthi, M., Orszag, M., and Orszag, P. (2001), 'Administrative costs under a decentralised approach to individual accounts: Lessons from the United Kingdom', in R. Holzmann and J. Stiglitz (eds), New Ideas About Old Age Security. Washington, DC: World Bank/Oxford University Press.

Musgrave, R. (1986), Public Finance in a Democratic Society, Vol li: Fiscal Doctrine, Growth and Institutions, New York: New York University Press.

ONS (2000a), Living in Britain. Results from the General Household Survey 1998, London: ONS.

ONS (2001), New Earnings Survey 1975 and 2000. London: The Stationery Office.

ONS (2002), Living in Britain. Results from the 2001 General Household Survey, London: The Stationery Office and http://www/statistics.gov.uk/

Orloff, A. (1993), 'Gender and the social rights of citizenship; the comparative analysis of gender relations and welfare states', American Sociological Review, 58, 303-328. 
Jay Ginn

Rake, K. (1999), 'Accumulated disadvantage? Welfare state provision and the incomes of older women and men in Britain, France and Germany', in J. Clasen (ed.), Comparative Social Policy Concepts: Theories and Methods, Oxford: Blackwell.

Schiewe, K. (1994), 'German pension insurance, gendered times and stratification', in D. Sainsbury (ed.), Gendering Welfare States, London: Sage.

Schokkaert, E. and van Parijs, P. (2003), 'Social justice and the reform of Europe's pension system', Journal of European Social Policy, 13, 3, 245-263.

Shragge, E. (1984), Pensions Policy in Britain: A Socialist Analysis, London: Routledge \& Kegan Paul.

Sinfield, A. (2000), 'Tax benefits in non-state pensions', European Journal of Social Security, 2, 2, 137-167.

Toporowski, J. (2000), The End of Finance, London: Routledge.

Waine, B. (1995), 'A disaster foretold? The case of the personal pension', Social Policy and Administration, 29, 4, 317-334.

Yamada, A. and Casey, B. (2002), 'Getting older, getting poorer ...', Occasional papers OECD, Paris. 